\title{
ASPECTOS JURÍDICOS DA (IN)COMPATIBILIDADE DO REGIME DE PRECATÓRIOS UTILIZADO NAS AÇÓES DE DESAPROPRIAÇÁO
}

\author{
Danilo Henrique Nunes ${ }^{1}$ \\ Universidade de Ribeirão Preto (UNAERP) \\ Lucas Souza Lehfeld ${ }^{2}$ \\ Universidade de Ribeirão Preto (UNAERP)
}

Centro Universitário Estácio de Ribeirão Preto

Artigo recebido em: 13/11/2019.

Artigo aceito em: 05/12/2019.

\section{Resumo}

Este artigo trata da utilizaçáo do regime de precatórios nas açóes de desapropriação reguladas pela CRFB/1988 e pelo Decreto-Lei n. 3.365, de 21 de junho de 1941 (Lei de Desapropriação por utilidade pública), decreto que foi recebido pela Carta maior, e expóe as controvérsias jurisprudências referentes à maneira de realizaçáo do pagamento da justa indenização abarcada quando da aplicação do instituto. Assim, a pesquisa descreve os aspectos históricos da Lei de Desapropriação por utilidade pública, a real necessidade de criação de lei infraconstitucional que regulamente o art. 5, $\$ 24$, da CRFB/1988, dispondo principalmente sobre o procedimento a ser adotado nas ações de desapropriaçáo no que tange ao pagamento das indenizaçóes. Assim, como meio de apresentar o impasse formado no judiciário, o presente se debruça sobre o Recurso Extraordinário n. 922144/MG de 2016, pelo ministro Luís Roberto Barroso, foi reconhecida a repercussão geral da presente controvérsia doutrinaria, servindo assim de fundamento à pesquisa, demonstrando a (in) compatibilidade da aplicação dos precatórios como modo de pagamento nas açôes de desapropriação.

Palavras-chave: desapropriação; direito à propriedade; Direito de Propriedade; segurança jurídica; utilidade pública.

1 Doutorando e Mestre em Direitos Coletivos e Cidadania UNAERP. Advogado, jornalista e professor universitário. ORCID: http://orcid.org/0000-0001-9162-3606 / e-mail: dhnunes@hotmail.com.

2 Pós-doutor em Direito pela Universidade de Coimbra. Doutor em Direito pela Pontifícia Universidade Católica de São Paulo (PUC-SP). Professor orientador do programa de Doutorado e Mestrado em Direitos Coletivos e Cidadania da UNAERP. Advogado. ORCID: http://orcid.org/0000-0002-3630-1134/e-mail: lehfeldrp@gmail.com.

3 Graduando do Curso de Direito do Centro Universitário Estácio de Ribeirăo Preto. E-mail: thalespedruci@hotmail.com. 


\section{LEGAL ASPECTS OF (IN) COMPATIBILITY OF THE PRECATORY SCHEME USED IN DISAPPROPRIA- TION ACTIONS}

\section{Abstract}

This article deals with the use of the precatory regime in the expropriation actions regulated by CRFB/1988 and Decree-Law No. 3.365, of June 21, 1941 (Public Expropriation Law), a decree that was received by the Major Charter, and It sets out the controversies in the case-law regarding the manner in which payment of the just compensation covered by the institute is paid. Thus, the research describes the historical aspects of the Expropriation Law for public utility, the real need to create an infraconstitutional law that regulates article 5, XXIV of $C R F B / 1988$, providing mainly about the procedure to be adopted in the ex- propriation actions in the compensation payments. Thus, as a way of presenting the impasse formed in the judiciary, the present one deals with the Extraordinary Appeal No. 922144/MG 2016, by Minister Luis Roberto Barroso, the general repercussion of the present doctrinal controversy was recognized, thus serving as a basis for the research, demonstrating the (in) compatibility of the application of the precatory as a form of payment in the expropriation actions.

Keywords: expropriation; legal security; Property Law; public utility; right to property. 


\section{Introdução}

A desapropriação como meio de intervençáo do Estado na propriedade particular respalda-se na Constituição Federal (BRASIL, 1988) e na legislação complementar, consistindo em um ato do Estado em que se transfere a propriedade de um particular para o patrimônio estatal de maneira compulsória mediante o pagamento prévio de justa indenização. O presente trabalho tem como objetivo analisar o instituto da desapropriação especialmente no tocante à prévia e justa indenização e as controvérsias referentes ao modo de pagamento realizado.

O direito de propriedade sofreu grandes modificaçóes ao longo da história até os dias atuais, e isso é condicionado ao atendimento da função social. Nos primórdios quando se firmou a ideia de apropriação do solo, a propriedade era vista com um caráter individualista ou, melhor dizendo, como um direito absoluto. Em constante evolução, esse direito à propriedade foi elevado a princípio constitucional, sendo o Estado obrigado a respeitar a propriedade, demonstrando o valor axiológico da função social, ou seja, como um valor constitucional para sua efetivação.

O objetivo geral da pesquisa busca, considerando os fundamentos jurídicos políticos da desapropriação no que se refere à indenizaçáo e, tendo em vista a controvérsia entre o texto constitucional, doutrinadores e entendimento dos tribunais relacionados à prévia indenização ou a sua submissão ao regime de precatórios, demonstrar qual o conceito de "prévia indenização" quando tratamos do instituto da desapropriação. Além disso, qual a compatibilidade da utilização do procedimento de pagamento por precatórios com a indenizaçáo prévia em dinheiro definida constitucionalmente?

Inicialmente, é demonstrado um breve histórico sobre a evolução do direito de propriedade, direito à propriedade e o condicionamento do exercício desse direito ao atendimento da função social, ou seja, a funcionalização da propriedade.

Posteriormente, buscam-se demonstrar os modos de intervenção do Estado na propriedade, bem como os princípios em que esses atos se fundamentam, com ênfase na supremacia do interesse público sobre o particular, estando diretamente relacionado à relativização do direito de propriedade.

Seráo demonstrados os pressupostos constitucionais da desapropriaçáo, essenciais para o procedimento expropriatório, além das diversas espécies de desapropriação como a fundamentada na necessidade pública ou utilidade pública, por interesse social, para fins de reforma agrária, desapropriação urbanística e desapropriação de confisco.

Por fim, aborda-se a previsão constitucional da indenização prévia e em 
dinheiro, presente no art. 50, inc. XXIV, da Constituição Federal (BRASIL, 1988), buscando o equilíbrio entre o interesse público e o privado, garantindo o direito de propriedade em favor do particular.

\section{Da desapropriação e suas modalidades}

A desapropriação é o modo originário de aquisição da propriedade, não dependendo, assim, de qualquer título anterior ou de relação direta com o antigo proprietário. Insta salientar que os procedimentos de intervenção do Estado na propriedade privada só poderão ser utilizados em caráter excepcional, tendo em vista que, em regra, a administração não interferirá na propriedade do particular. Logo, é necessária a demonstração dos pressupostos previstos na legislação, assim sintetizados: necessidade pública, utilidade pública e interesse social.

Essa modalidade de intervenção é a denominada supressiva, na qual há a transferência compulsória da propriedade de seu dono para o Estado, ou seja, a maneira mais drástica e agressiva de intervenção, acarretando a perda da propriedade mediante o pagamento da justa indenização.

A fonte primária da desapropriação está no art. 5º, inc. XXIV, da Constituição (BRASIL, 1988). Portanto, como consta da parte final da norma, há exceçôes ao pagamento da indenização em dinheiro, que diz respeito às outras espécies de desapropriação, sendo que a desapropriação por interesse, necessidade pública ou interesse social é denominada pela doutrina como desapropriação comum ou ordinária.

A Constituição traz, igualmente, o fundamento para outras espécies de desapropriação que não serão abordadas profundamente, mas como exemplos que têm base constitucional no art. $182, \S 4^{\circ}$, inc. III - que trata da desapropriação em razão de descumprimento da função social do Plano Diretor; no art. 184 -, que versa sobre a desapropriação por interesse social, para fins de reforma agrária; e no art. 243 - que é a denominada desapropriação confiscatória. São diversas as normas legais que tratam do instituto, sendo, em síntese, as mais relevantes: o Decreto-Lei n. 3.365/41 que, embora discipline especialmente a desapropriação por utilidade pública, o diploma é considerado a lei geral de desapropriaçôes, contendo as normas mais importantes sobre o procedimento expropriatório.

Já a Lei n. 4.132/62 (BRASIL, 1962) disserta sobre os casos de desapropriação por interesse social. Em outro sentido, a Lei n. 8.629/93 (BRASIL, 1993) regulamenta os dispositivos constitucionais referentes à reforma agrária. A Lei n. 10.257/2001 (Estatuto da Cidade) regulamenta a desapropriação urbanística (art. $8^{\circ}$ ), de competência do município, como importante instrumento de política urbana (BRASIL, 2001).

Para a presente análise, é importante o Decreto-Lei n. 3.365, de 21 de junho 
de 1941, que cuida da desapropriação por necessidade e utilidade pública. O art. $5^{\circ}$ do Decreto-Lei traz hipóteses de necessidade e utilidade pública. O decreto-lei não traz a expressão necessidade, que foi contemplada pela Constituição, mas coloca sempre no mesmo contexto a utilidade e a necessidade como a diferença prevista na urgência diante de cada caso concreto.

A utilidade pública estará presente nas situaçóes em que o Estado pretende fazer uso do bem, ele vai dar uma finalidade a esse bem, entáo usará o bem para realizar uma obra ou serviço, mas será utilizado diretamente pelo Estado. A doutrina costuma dizer que a diferença entre a utilidade e a necessidade é a urgência. Então, se houver a utilidade pública e se for urgente sua realização, existe uma necessidade pública.

$\mathrm{O}$ art. $5^{\circ}$ do Decreto-Lei n. 3.365/41 (BRASIL, 1941) descreve as seguintes hipóteses de utilidade pública para fins de desapropriação: (a) a segurança nacional; (b) a defesa do Estado; (c) o socorro público em caso de calamidade; (d) a salubridade pública; (e) a criação e melhoramento de centros de população, seu abastecimento regular de meios de subsistência; (f) o aproveitamento industrial das minas e das jazidas minerais, das águas e da energia hidráulica; (g) a assistência pública, as obras de higiene e decoração, casas de saúde, clínicas, estaçôes de clima e fontes medicinais; (h) a exploração ou a conservação dos serviços públicos; (i) a abertura, conservação e melhoramento de vias ou logradouros públicos; a execução de planos de urbanização; o parcelamento do solo, com ou sem educação, para sua melhor utilização econômica, higiênica ou estética; a construção ou ampliação de distritos industriais; (j) o funcionamento dos meios de transporte coletivo; (k) a preservação e conservação dos monumentos históricos e artísticos, isolados ou integrados em conjuntos urbanos ou rurais, bem como as medidas necessárias a fim de lhes manter e realçar os aspectos mais valiosos ou característicos e, ainda, a proteção de paisagens e locais particularmente dotados pela natureza; (l) a preservação e a conservação adequada de arquivos, documentos e outros bens móveis de valor histórico ou artístico; (m) a construção de edifícios públicos, monumentos comemorativos e cemitérios; (n) a criação de estádios, aeródromos ou campos de pouso para aeronaves; (o) a reedição ou divulgação de obra ou invento de natureza científica, artística ou literária; e (p) os demais casos previstos por leis especiais.

Sobre o tema, José dos Santos Carvalho Filho (2018 p. 993) afirma que:

Ocorre a utilidade pública quando a transferência do bem se afigura conveniente para a Administração. Já a necessidade pública é aquela que decorre de situaçôes de emergência, cuja solução exija a desapropriação do bem. Embora o texto constitucional se refira a ambas as expressôes, o certo é que a 
noção de necessidade pública já está inserida na de utilidade pública. Esta é mais abrangente que aquela, de modo que se pode dizer que tudo que for necessário será fatalmente útil. A recíproca é que não é verdadeira: haverá desapropriaçôes somente úteis, embora não necessárias. Quando nos referirmos, pois, à utilidade pública, devemos entender que os casos de necessidade pública estarão incluídos naquele conceito mais abrangente. Exemplo de utilidade pública: a construção de uma escola pública ou de um centro de assistência social do Estado.

A desapropriação por interesse social está regulamentada pela Lei n. 4.132, de 10 de setembro de 1962, definindo que haverá interesse social todas as vezes que o Estado desapropriar o bem para garantir a funçáo social da propriedade (BRASIL, 1962). Então aqui o Estado busca dar função social a propriedade, não é necessariamente uma utilização direta do Estado, fato pelo qual se diferencia diante da necessidade ou utilidade pública. De acordo com José dos Santos Carvalho Filho (2018 p. 963):

$\mathrm{O}$ interesse social consiste naquelas hipóteses em que mais se realça a função social da propriedade. O Poder Público, nesses casos, tem preponderantemente o objetivo de neutralizar de alguma forma as desigualdades coletivas. Exemplo mais marcante é a reforma agrária, ou o assentamento de colonos.

Brilhante decisão do STF, proferida pelo ministro Celso de Mello, complementa a ideia:

[...] O direito de propriedade não se reveste de caráter absoluto, eis que, sobre ele, pesa grave hipoteca social, a significar que, descumprida a função social que lhe é inerente ( $\mathrm{CF}$, art. 5o, XXIII), legitimar-se-á a intervenção estatal na esfera dominial privada, observados, contudo, para esse efeito, os limites, as formas e os procedimentos fixados na própria Constituição da República. O acesso a terra, a solução dos conflitos sociais, o aproveitamento racional e adequado do imóvel rural, a utilização apropriada dos recursos naturais disponíveis e a preservação do meio ambiente constituem elementos de realização da função social da propriedade. A desapropriação, nesse contexto - enquanto sançâo constitucional imponível ao descumprimento da função social da propriedade - reflete importante instrumento destinado a dar consequência aos compromissos assumidos pelo Estado na ordem econômica e social. Incumbe, ao proprietário da terra, o 
dever jurídico-social de cultivá-la e de explorá-la adequadamente, sob pena de incidir nas disposiçóes constitucionais e legais que sancionam os senhores de imóveis ociosos, não cultivados e/ou improdutivos, pois só se tem por atendida a função social que condiciona o exercício do direito de propriedade, quando o titular do domínio cumprir a obrigação (1) de favorecer o bem-estar dos que na terra labutam; (2) de manter níveis satisfatórios de produtividade; (3) de assegurar a conservação dos recursos naturais; e (4) de observar as disposiçóes legais que regulam as justas relaçôes de trabalho entre os que possuem o domínio e aqueles que cultivam a propriedade. [...] (ADI $2.213 \mathrm{MC} / \mathrm{DF}$, STF - Tribunal Pleno, Rel. Min. Celso de Mello, julgamento 04.04.2002, DJ 23.04.2004, p. 7).

A Lei n. 4.132/62, por sua vez, dispõe, em seu art. $2^{\circ}$, sobre o interesse social: (a) o aproveitamento de todo bem improdutivo ou explorado sem correspondência às necessidades de habitação, ao trabalho e ao consumo dos centros de população a que deve ou possa suprir por seu destino econômico; (b) o estabelecimento e a manutenção de colônias ou cooperativas de povoamento e trabalho agrícola; (c) a manutençáo de posseiros em terrenos urbanos onde, com a tolerância expressa ou tácita do proprietário, tenham construído sua habitaçáo, formando núcleos residenciais de mais de 10 (dez) famílias; (d) a construção de casas populares; (e) as terras e águas suscetíveis de valorização extraordinária pela conclusão de obras e serviços públicos, notadamente de saneamento, portos, transporte, eletrificação, armazenamento de água e irrigação, no caso em que não sejam as ditas áreas socialmente aproveitadas; (f) a proteção do solo e a preservação de cursos e mananciais de água e de reservas florestais; e (g) a utilização de áreas, locais ou bens que, por suas características, sejam apropriados ao desenvolvimento de atividades turísticas (BRASIL, 1962).

A desapropriação, portanto, ressalvadas as exceçóes previstas e brevemente supramencionadas, tem como base três pilares. Primeiro, a demonstração do interesse público que pode ser utilidade, necessidade pública ou interesse social. Além do interesse público a desapropriação depende também do pagamento de indenização que deve ser prévia em dinheiro. A indenização prévia significa a indenização antes da perda da propriedade do bem. Em dinheiro significa em real, ou seja, em moeda corrente do país. Por fim, a indenização deverá ser justa; teoricamente essa indenizaçáo será calculada por meio da administração, pelo perito, abarcando o valor venal do imóvel, valor de mercado daquele imóvel. Agora se tem a hipótese também, além do valor de mercado, abrange todos os danos que o proprietário 
terá com a desapropriação. A avaliação justa será, então, o valor venal de mercado somado a todos os danos que o particular terá com o ato supressivo do Estado.

$\mathrm{O}$ art. $2^{\circ}$ do Decreto-Lei n. 3.365/41 (BRASIL, 1941) estabelece que "todos os bens podem ser desapropriados” pelas entidades da Federação, portanto há uma grande variedade de objetos sobre os quais a desapropriação pode recair. No entanto, não restam dúvidas de que em quase todos os casos o ato expropriatório é realizado sobre bens imóveis, sendo que não seria relevante apontar todos os bens que podem ser desapropriados. O trabalho também apresentará a maioria das situações fáticas enfrentadas pelo judiciário em que o objeto da desapropriação é um bem imóvel, porém não se pode deixar de esclarecer que é o único que pode sofrer esse ato, seja restritivo ou supressivo.

Com base no Decreto-Lei n. 3.365/41 (BRASIL, 1941), que fundamenta o procedimento para os casos de necessidade, utilidade pública ou interesse social, que é o objeto do presente trabalho, analisaremos que esse procedimento é dividido em duas fases: a declaratória e a executória.

A primeira fase declaratória se destaca pela manifestação de vontade do Poder Público em proceder desapropriação. Caracteriza-se por ser um ato administrativo por meio do decreto expropriatório ou por publicação da lei expropriatória (arts. $6^{\circ}$ e $8^{\circ}$ do Decreto-lei n. 3.365/41), ou seja, por decreto do chefe executivo ou uma lei de efeitos concretos para declarar a necessidade utilidade pública ou interesse social.

$\mathrm{O}$ ato declaratório, seja decreto ou lei, deverá indicar o sujeito passivo da desapropriação, a descrição do bem, a declaração de utilidade pública ou interesse social, a destinação específica a ser dada ao bem, o fundamento legal e os recursos orçamentários destinados ao atendimento da despesa. Esse ato, por si só, não retira a propriedade do particular imediatamente, mas cria um direito subjetivo do expropriante de proceder à expropriação do bem indicado, partindo para os posteriores atos administrativos e, dependendo do caso concreto, para a prática de atos judiciais, consumando, assim, após a fase executória à desapropriação.

Nesse sentido, de acordo com Medauar (2018, p. 355-356):

A declaração expropriatória, também denominada ato expropriatório, é um ato administrativo anunciador da desapropriaçáo de um bem; em geral vem acompanhado de planta indicativa do bem a ser expropriado, quando imóvel. A declaração expropriatória menciona o preceito legal em que se enquadra a desapropriação anunciada e deve ser publicada no jornal oficial.

A declaração somente anuncia que o bem aí descrito será expropriado. Não opera a transferência da propriedade ou da posse do 
bem, apenas vai desencadear as demais fases. Sem a declaraçáo nenhum outro ato ou medida poderá ser efetuado pela Administração.

A simples declaração de utilidade pública não se constitui em ato expropriatório. Essa declaração gera determinadas consequências, podendo o Estado penetrar, sem necessidade de autorização judicial e maneira administrativa, no bem para fazer mediçóes, avaliaçóes no terreno e para definir o valor indenizatório, ou seja, não tem o objetivo de já efetivar a desapropriação, mas sim de buscar, nesse momento, fixar o estado do bem. Essa fixação consiste no ato do Poder Público em dizer que almeja o bem no estado em que se encontra naquele momento, sendo futuras melhorias realizadas, em regra, não ressarcidas. Em regra, as melhorias feitas no bem após a declaração não serão objeto de ressarcimento, as exceçôes encontram-se nas benfeitorias necessárias e nas úteis, desde que tenham sidas autorizadas.

Com a declaração de utilidade pública ou interesse social, conclui-se que o bem ainda não deixou de ser propriedade particular, porém o particular ficou sujeito a restrições antes mesmo de receber o valor da indenização, por exemplo, o Poder Público penetrar no bem e fixar seu estado. Por isso, essa declaração deve ser executada; ela tem um prazo de caducidade. Caso não seja executada dentro desse prazo, ela decai e não há mais como ser executada.

Caso seja uma declaração de utilidade ou necessidade pública, o prazo decai em cinco anos; na situação de interesse social, decai em dois anos. Procedida a declaração, tem-se um prazo de caducidade, depois de passado o prazo não tem como executar. Porém o poder público, diante dessa situaçáo, pode declarar novamente a utilidade ou necessidade pública ou interesse social, mas deve respeitar o prazo de um ano de carência. A ideia é que a emenda de uma declaração na outra sujeita o bem a uma eterna força expropriatória do Estado.

Posteriormente, após a fase declaratória em que se manifesta o interesse no imóvel de propriedade privada, inicia-se a fase executória, na qual o expropriante começa a tomar medidas buscando a incorporação do bem ao acervo do Estado. É nessa fase que vai realmente se concretizar a transferência da propriedade para o expropriante, que poderá se dar a extinção de maneira administrativa ou judicial.

Essa fase pode ser procedida pelos poderes federativos (União, estados, municípios e Distrito Federal) pelos entes da administraçáo indireta. A competência executória também pode ser delegada aos consórcios públicos e às concessionárias de serviço público - neste último, desde que haja previsão em lei ou em contrato realizada com a Administração Pública.

Portanto, se houver a declaração com todas as suas especificaçôes, o Poder 
Público poderá buscar um acordo extrajudicial da desapropriação com o particular atingido. Desse modo, como esse ato, posteriormente, acarretará uma transferência compulsória do bem pertencente ao particular ao patrimônio do Estado, poderá, entâo, o particular, caso entenda que a oferta feita pelo bem seja justa, realizar o acordo com o expropriante esgotando, assim, tal procedimento na via administrativa, ou seja, sem a necessidade de levar o conflito ao judiciário. Esse esgotamento sem a necessidade da intervenção do judiciário é chamado de desapropriação amigável.

$\mathrm{Na}$ fase executória, se houver acordo entre particular e Estado, a desapropriação se encerra na via administrativa. Se não houver acordo, a solução se dá na via judicial por meio de uma demanda expropriatória ou ação de desapropriação. A única defesa de mérito que pode ser alegada pelo particular é a que diz respeito ao valor da indenização, sendo qualquer outra ilegalidade do ato de desapropriação devendo ser alegada em ação própria (ação direta anulatória) a ser ajuizada.

Por isso, diante desse raciocínio que a única matéria possível a ser alegada pelo particular na contestaçáo é sobre o valor da indenização, quando da resoluçáo da ação; o particular ao depender da devida instrução receberá uma quantia em dinheiro em contrapartida à perda da propriedade do bem. Nessa perspectiva, é importante ressaltar a possibilidade da imissão na posse provisoriamente sobre o argumento, uma vez que, declarada a necessidade pública (aqui relação com a diferença apresentada no tocante à urgência), depositado um valor incontroverso em juízo e, sendo o quantum indenizatório a única matéria de defesa, o julgador poderá conceder a imissão provisória na posse do bem. A imissão provisória na posse nada mais é que a transferência de um dos poderes inerentes ao bem ao Estado: o poder da posse, podendo se utilizar da posse para realização dos atos necessários que fundamentam a urgência declarada.

São necessários, portanto, a declaração de urgência (geralmente, feita na declaração expropriatória) e o depósito de um valor incontroverso em juízo (em geral, feito por um laudo inicial apresentado quando da propositura da ação de desapropriação). No momento em que o Estado se imite na posse do bem, o expropriado poderá levantar $80 \%$ do valor depositado, sendo que os outros $20 \%$ ficarão como garantia do juízo. Cabe ressaltar que se o expropriado optar por levantar $100 \%$ do valor depositado em juízo, entende-se como se tivesse acordado com o valor total a ser pago sobre o bem declarado, extinguindo o processo nessa fase.

Com a decisão final transitada em julgado (sem a possibilidade da interposição de recursos), com a formação da coisa julgada, ocorre a aquisição da propriedade pelo poder público, no qual, até então, só detinha a posse do bem, sendo o registro apenas para eficácia. 
O que se pode verificar na prática é que, na maioria das vezes, a desapropriação não se finda na esfera administrativa por meio do acordo entre as partes, sendo posteriormente necessária a utilização da via judicial para solucionar o conflito entre o particular e o Estado.- Nesse caso, o expropriante ingressará com a ação de desapropriação por utilidade, necessidade pública ou interesse social, discutindo-se apenas o valor da justa indenização já que após a fase declaratória, a propriedade será transferida de maneira compulsória.

Podemos concluir que o procedimento tem natureza administrativa; a princípio, com a fase declaratória e, posteriormente, com o início da fase executória a intervenção poderá se concretizar já na fase administrativa por meio de consenso entre o particular e o Estado com referência ao valor ofertado ou, caso as partes náo cheguem a um acordo, o procedimento passará à via judicial, decidindo-se o valor da justa indenização com a concretização do ato expropriatório.

\section{Das controvérsias doutrinárias e jurisprudenciais so- bre a (in)compatibilidade da indenizaçáo com o regime de precatórios}

Após a fase declaratória da desapropriação, com o seguimento para a fase executória, é certo que o bem será expropriado, restando apenas em síntese a discussão acerca da devida indenização. A grande discussão se dá justamente no tocante à forma de pagamento da indenizaçáo justa prevista no procedimento expropriatório, uma vez que haja uma divergência concreta entre a jurisprudência e os tribunais superiores.

A Constituição de 1988, em seu art. 5º, inc. XXIV, define que a indenização paga ao expropriado deve ser prévia, justa e em dinheiro. Por sua vez, a norma constitucional do art. 100 prevê que os pagamentos devidos pela Fazenda Pública decorrentes de sentenças judiciais deverão ser realizados exclusivamente por precatórios, salvo exceção referente às obrigaçôes, que são definidas como de pequeno valor (art. 100, $\left.\$ 3^{\circ}\right)$.

Uma corrente defende que o regime de precatórios deve ser utilizado para o pagamento de demandas que resultam na desapropriação, geralmente, com o fundamento na regulamentaçáo e estabilização das finanças públicas e outra corrente privilegia a indenização prévia, justa e em dinheiro, afastando o regime de precatórios para o pagamento dessas indenizaçóes sob a égide da força dos direitos e das garantias fundamentais tratados como cláusulas pétreas no art. $5^{\circ}$, caput e incs. 22 e 24 .

A problemática, portanto, encontra-se atualmente nas açóes expropriatórias. 
Ainda, que haja o referido amparo, mormente, realizada, por meio de precatório, a indenização perde seu caráter prévio e em dinheiro, ensejando o questionamento que norteia o presente estudo, quanto à compatibilidade ou não da aplicação do art. 100 da Constituição (BRASIL, 1988) com o instituto da desapropriação por necessidade ou utilidade pública, e a predisposiçâo em se assimilar que inexiste consonância com o referido sistema.

A (in)compatibilização foi analisada pelos tribunais de justiça do país, além de ser debatida no Supremo Tribunal Federal, em que se reconheceu a repercussão geral da questão. $\mathrm{O}$ que se pode extrair dos julgamentos é que ainda não há um posicionamento definido, ou seja, a divergência presente no conflito de normas ainda é presente, tendo duas teses antagônicas acerca do tema.

\subsection{Possibilidade do pagamento mediante regime de precatório}

A respeito do regime de precatórios, podemos indicar a clara definição dada por Tathiane Piscitelli (2012, p. 172):

O reconhecimento judicial de um crédito perante uma pessoa jurídica de direito público é o pressuposto inicial para que possamos cogitar da análise dos precatórios. Diante desse reconhecimento, que deve se operar por decisão transitada em julgado, o juiz da execução encaminha ao Presidente do Tribunal respectivo uma solicitação, para que este requisite verba necessária para o julgamento do credor. Essa solicitação é o precatório, cuja disciplina geral se encontra no art. 100 da Constituiçáo. Tendo recebido o precatório, o Presidente do tribunal determinará sua numeração e apresentará um comunicado à Fazenda Pública, que deverá efetivar o pagamento respectivo, na ordem cronológica de apresentaçáo dos precatórios. Referido pagamento depende da liberaçấo, pelo poder executivo, das verbas orçamentárias consignadas exclusivamente para este fim. Essa liberação é feita em nome do Presidente do Tribunal, que recebe os recursos e os encaminha para o juízo da execuçáo, para que este realize o pagamento das dívidas pendentes.

Pela definiçấo dada anteriormente, conclui-se que a adoção do regime de precatórios visa prevalecer o Estado, na medida em que permite a programaçáo para efetuar pagamento que advier de decisão judicial, sendo assim uma norma constitucional e importante para a organizaçáo financeira dos entes que procederão ao pagamento. 
Diante dos casos concretos, os tribunais vêm se deparando com o conflito entre as normas constitucionais suscitadas, sendo que, em prol do seguimento pelo procedimento dos precatórios, o relator do Agravo de Instrumento de n. 0620842-85.2015.8.06.000052, desembargador Washington Luis Bezerra de Araújo, posicionou-se:

AGRAVO DE INSTRUMENTO. DIREITO CONSTITUCIONAL E ADMINISTRATIVO. AÇÃO DE DESAPROPRIAÇÃO. COMPLEMENTAÇÃO DA INDENIZAÇÃO JUSTA, PRÉVIA E EM DINHEIRO. IMPOSSIBILIDADE DE CONDICIONAMENTO DO DEPÓSITO, POIS NÃO EXCEPCIONA O SISTEMA CONSTITUCIONAL DE PRECATÓRIOS (CF/88, ART. 100). RECURSO CONHECIDO E PROVIDO.

1. A indenização justa e prévia será em dinheiro apenas aquela que ocorre antes da transferência do domínio do bem desapropriado, restando o que ficar definido na sentença submetido às requisiçóes de pequeno valor ou ao sistema de precatórios, a depender do montante.

2. Com exceção do previsto no art. 100, $\$ 3^{\circ}$, (requisição de pequeno valor), da Constituição Federal de 1988, reputa-se inadmissível outra forma de pagamento devido em virtude de sentença judiciária que não o precatório. Precedentes do STF.

3. Recurso conhecido e provido.

Nas ações expropriatórias, quando há a discussão judicialmente acerca indenização, percebe-se que ainda há um entendimento de adoção do regime de precatórios, visto que, como mencionado na norma do art. 100 da Constituição de 1988, seguirão esse procedimento valores que forem fixados em sentença contra a Fazenda Pública.

O ministro Marco Aurélio, nesse sentido, em uma de suas decisóes, defende que o procedimento cautelar do art. 100 é uma exceção contida no que diz respeito à norma do art. $5^{\circ}$, inc. XXIV, da Constituição:

DESAPROPRIAÇÃO - VERBA INDENIZATÓRIA - DECISÃO JUDICIAL. O cumprimento de decisão judicial na qual vencida entidade pública faz-se mediante precatório. Essa forma está compreendida nas exceçôes versadas na cláusula final do inciso XXIV do art. $5^{\circ}$ da Constituição Federal (BRASIL, 1988). 
Em alguns precedentes, posiciona-se o STF:

AGRAVO REGIMENTAL NO RECURSO EXTRAORDINÁRIO. CONSTITUCIONAL E ADMINISTRATIVO. DESAPROPRIAÇÃO. DEPÓSITO PRÉVIO INSUFICIENTE. IMISSÃO NA POSSE. PAGAMENTO DA DIFERENÇA POR MEIO DE PRECATÓRIO. AGRAVO REGIMENTAL AO QUAL SE NEGA PROVIMENTO.

AGRAVO REGIMENTAL NO RECURSO EXTRAORDINÁRIO. DESAPROPRIAÇÃO. IMISSÃO NA POSSE. DEPÓSITO PRÉVIO. VALOR INSUFICIENTE. DIFERENÇA. PRECATÓRIO. Verificada a insuficiência do depósito prévio na desapropriação por utilidade pública, a diferença do valor depositado para imissáo na posse deve ser feito por meio de precatório, na forma do art. $100 \mathrm{da} C B / 88$. Agravo regimental a que se nega provimento (BRASIL, 1988).

É necessário considerar que o regime de precatórios é fundamental para organização financeira do Estado, uma vez que exceçôes a esse procedimento devem ser avaliadas com muito cuidado visando a não desestabilização das finanças públicas, fundamentos pelos quais se inserem nas decisões a favor desse procedimento.

\subsection{Da previsão constitucional da indenização prévia e em dinheiro}

Em defesa de modo indenizatório prévia e justamente ao particular, deve-se ressaltar que, diante de um ato intrusivo do Estado no direito constitucional de propriedade garantido ao indivíduo, é de suma importância a indenização prévia como maneira de restaurar o status quo ante. A indenização é justamente prevista como modo de reparar o "dano" que o Estado causou ao particular, podendo ser de extrema urgência, especialmente nos casos em que o privado que está sofrendo o ato supressivo e todos que dele dependem, por exemplo, possui como único bem o que será expropriado, sendo o dinheiro recebido como pagamento aquele que será utilizado para investimento em um novo bem.

Em consonância com a prévia indenização, no Tribunal do Estado do Paraná no Agravo de Instrumento de número 1382955-951, tendo como relator o Desembargador Carlos Mansur Arida (PARANÁ, 2015), defende claramente a indenização prévia e em dinheiro, senão, vejamos: 
DECISÃO: ACORDAM os Desembargadores integrantes da Quinta Câmara Cível do Tribunal de Justiça do Estado do Paraná, por unanimidade de votos, em dar provimento ao recurso. EMENTA: EMENTA: AGRAVO DE INSTRUMENTO. DESAPROPRIAÇÃO INDIRETA. OFENSA AOS DIREITOS E GARANTIAS FUNDAMENTAIS (ART. 5 CAPUT E INCISOS XXII E XXIV, CF). CLÁUSULAS PÉTREAS. PODER PÚBLICO QUE NÃO ESTÁ IMUNE À CONSTITUIÇÃO. PAGAMENTO DA INDENIZAÇÃO. ART. 100, CF.NORMA QUE NÃO É ABSOLUTA. PRECATÓRIO REQUISITÓRIO. PRERROGATIVA AFASTADA.RECURSO PROVIDO. Ao suplantar o dever constitucional de agir de acordo com a legalidade e privar o cidadáo de seus bens sem o devido processo legal, o Município deve ser despido de uma de suas prerrogativas, qual seja, o privilégio de pagar os débitos judiciais de forma distinta, pois é inadmissível que a violação dos mandamentos constitucionais seja muito mais vantajosa ao Poder Público do que o seu cumprimento.- A aplicação do art. 100 não é absoluta, devendo ser excepcionalmente afastada no caso dos autos para dar lugar à imediata materialização dos arts. $5^{\circ}$ e $182, \$ 3^{\circ}$, CF, bem como para reprimir o ente municipal violador da Carta Magna.

Em decisão recente, o Tribunal de Justiça do Estado de Goiás (GOIÁS, 2017) se póe no mesmo sentido. Vejamos a seguir:

DESAPROPRIAÇÃO INDIRETA. INDENIZAÇÃO EM DINHEIRO. OBSERVÂNCIA AO ART. 5', XXIV, CF. RECURSO SECUNDUM EVENTUM LITIS. DESPROVIMENTO. I $\mathrm{O}$ agravo de instrumento é recurso secundum eventum litis, ficando seu conhecimento restrito ao conteúdo da decisão agravada, seu acerto ou desacerto. II - Para a concessão de tutela de urgência, revela-se necessária a satisfação dos pressupostos enunciados no art. 300 do CPC/2015: a probabilidade do direito invocado (fumus boni iuris) e o perigo de dano ou o risco ao resultado útil do processo (periculum in mora), além da inexistência do perigo da irreversibilidade. III - Na desapropriação indireta o pagamento em dinheiro constitui garantia constitucional alinhada no art. $5^{\circ}$, XXIV da carta republicana, inadmissível o pagamento na forma de precatório, sob pena de subverter o referido preceito constitucional, além de tratar de forma desiguais situaçóes que se direcionam ao mesmo objetivo, qual seja, garantir ao expropriado 
o recebimento prévio do valor que lhe é devido. IV - Agravo de instrumento desprovido.

Em contrapartida às decisóes que fixam o regime de precatório, é de se pensar que rebatendo o argumento da organização orçamentária para pagamento da indenização, o Estado, ao verificar a necessidade da desapropriaçáo, só deverá iniciá-la quando tiver previsão concreta de pagamento por meio de uma profunda análise no bem com a fixação do valor justo a ser pago.

De importante relevância para o estudo, cabe ressaltar o julgamento da ADI 2.332. A ação teve início em 18 de maio de 2000, quando a OAB buscou, em síntese, a declaraçáo de inconstitucionalidade contra dispositivos inseridos pela Medida Provisória 2.027-43/2000 e demais reediçóes, que alterou o Decreto-Lei 3.365/1941, mais especificamente o art. 15-A, que se refere à imissão prévia na posse, na desapropriação por necessidade ou utilidade pública e interesse social, até mesmo para fins de reforma agrária - e os parágrafos do art. 27, pois, em seus textos, limitava o pagamento de juros compensatórios em desapropriaçóes em até $6 \%$ ao ano e definia sua base de cálculo sobre o valor da diferença entre o preço ofertado pelo Estado em juízo e o valor fixado na sentença; condicionava os juros compensatórios a compensar a perda de renda comprovadamente sofrida pelo proprietário e à comprovação de que os graus de utilização da terra (GUT) e eficiência na exploração (GEE) não fossem iguais a zero; limitava a retroação do pagamento no tempo e os honorários advocatícios a um teto nominal fixo, devendo ser estabilizados entre $0,5 \%$ e $5 \%$ do valor da diferença, não podendo os honorários ultrapassar o valor de R\$ 151.000,00 (na época da edição da Medida Provisória).

Em 5 de setembro de 2001, o STF, em julgamento liminar, deferiu em parte o pedido, suspendendo a eficácia da expressão "de até 6 por cento ao ano", ou seja, removendo a limitaçáo do alcance dos juros compensatórios (voltando ao entendimento anterior fixado na Súmula 618 do STF, publicada em 1984, que previa percentual de $12 \%$ ao ano para os juros compensatórios), e suspendeu o teto fixado de honorários, porém manteve os percentuais mínimos e máximos. A partir da prolação da decisão, os órgãos jurisdicionais começaram a se posicionar de modo a observar o entendimento provisório proferido pelo STF.

Após quase 18 anos de ajuizada a ação, em 17 de maio de 2018, o mérito da ADI foi julgado, apresentando uma leve mudança no tocante à liminar decidida anteriormente, em que foi definida a constitucionalidade da aplicação dos juros compensatórios de 6\%, alegando-se plena consonância com as aplicaçôes que existem no mercado financeiro, sendo considerada inconstitucional a expressão "até". A base de cálculo foi mantida conforme prevista no art. 15-A 
do Decreto-Lei 3.365/1941, incidindo juros compensatórios sobre a diferença entre $80 \%$ do preço ofertado pelo Estado e o valor indenizatório fixado na sentença judicial. $\mathrm{O}$ estabelecimento do teto de honorários advocatícios previsto no $\$ 1^{\circ}$ do art. 27 também foi considerado inconstitucional.

Após divergências, consideram-se constitucionais as restrições à incidência dos juros compensatórios do art. 15-A, $\$ 1^{\circ}$ (quando não houver comprovação de efetiva perda de renda pelo proprietário com a imissão provisória na posse) e do art. $15-\mathrm{A}, \$ 2^{\circ}$ (quando o imóvel tiver graus de utilização da terra e de eficiência na exploração iguais a zero). Prevaleceu o entendimento de que a previsão dos juros compensatórios tem fundamento somente quando demonstrada a efetiva perda de renda sofrida pelo proprietário do bem desapropriado.

Vejamos o constante do acórdão:

Decisão: O Tribunal julgou parcialmente procedente a ação direta para: i) por maioria, e nos termos do voto do Relator, reconhecer a constitucionalidade do percentual de juros compensatórios de $6 \%$ (seis por cento) ao ano para remuneração do proprietário pela imissáo provisória do ente público na posse de seu bem, declarando a inconstitucionalidade do vocábulo "até", e interpretar conforme a Constituição o caput do art. 15-A do Decreto-Lei $3.365 / 41$, de 21 de junho de 1941, introduzido pelo art. $1^{\circ}$ da Medida Provisória n. 2.027-43, de 27 de setembro de 2000, e suas sucessivas reediçóes, de maneira a incidir juros compensatórios sobre a diferença entre $80 \%$ (oitenta por cento) do preço ofertado em juízo pelo ente público e o valor do bem fixado na sentença, vencido o Ministro Marco Aurélio, que julgava procedente o pedido, no ponto, em maior extensão; ii) por maioria, vencidos os Ministros Roberto Barroso (Relator), Luiz Fux e Celso de Melo, declarar a constitucionalidade do $\$ 1^{\circ}$ e do $\$$ $2^{\circ}$ do art. 15-A do Decreto-Lei 3.365/41; iii) por unanimidade, e nos termos do voto do Relator, declarar a constitucionalidade do $\$ 3^{\circ}$ do art. 15-A do Decreto-Lei 3.365/41; iv) por maioria, e nos termos do voto do Relator, declarar a inconstitucionalidade do $\$ 4^{\circ}$ do art. 15-A do Decreto-Lei 3.365/41, vencido o Ministro Marco Aurélio; v) por unanimidade, e nos termos do voto do Relator, declarar a constitucionalidade da estipulaçáo de parâmetros mínimo e máximo para a concessão de honorários advocatícios previstos no $\$ 1^{\circ}$ do art. 27 o Decreto-Lei 3.365/41 e declarar a inconstitucionalidade da expressão "náo podendo os honorários ultrapassar R \$ 151.000,00 (cento e cinquenta e um 
mil reais)". Ausente, justificadamente, o Ministro Dias Toffoli, em face de participação, na qualidade de representante do Supremo Tribunal Federal, no VIII Fórum Jurídico Internacional de São Petersburgo, a realizar-se na Rússia. Falaram: pelo requerente, o Dr. Oswaldo Pinheiro Ribeiro Júnior; e, pelo Presidente da República, a Dra. Grace Maria Fernandes Mendonça, Advogada-Geral da União. Presidiu o julgamento a Ministra Cármen Lúcia. Plenário, 17.5.2018.

Essa decisão, em razão de todo seu conteúdo, poderá ser objeto de várias discussóes sobre o controle de constitucionalidade, o que não tem relação com presente artigo. Porém, nesse ponto, não veio a ser debatida a questão sobre os efeitos dessa decisáo no tempo, ou seja, se a eficácia seria aplicada desde a data da decisão liminar proferida em 2001 ou somente a partir da decisão de julgamento do mérito. É com base nessa decisão que podemos fazer correlação com este trabalho, tendo como objeto a (in)compatibilidade do regime de precatórios nas açóes expropriatórias. No caso da ADI apresentada, verificou-se uma grande demora de resposta por parte do Tribunal Superior e da decisão de mérito; há, no momento, uma divergência de entendimentos de sua eficácia e sua aplicabilidade.

A questão é que, na prática, as açôes expropriatórias, na maioria das vezes, em razão de o conflito ser levado ao judiciário, tem uma demanda morosa em decorrência de suas peculiaridades e de seu procedimento, pela indenização ao particular demorar para se concretizar (perícia judicial, necessidade de definição de juros compensatórios, necessidade de demonstração da efetiva perda de renda pelo proprietário com a imissão provisória na posse e/ou comprovação de que o imóvel tenha graus de utilização da terra e de eficiência na exploração não iguais a zero).

Marco Túlio Reis Magalhães cita, brilhantemente, a ressalva de Alexandre de Moraes nos fundamentos da ADI:

O ministro Alexandre de Moraes também ressaltou que os cenários econômicos (à época da Súmula 618/STF e à época da edição da MP em análise) eram totalmente diversos e que a manutenção da cautelar, quanto ao percentual de juros aplicado, seria a transformação "da justa indenização para uma injusta indenização, mas em relaçấo ao Poder Público", inclusive com o fomento de um mercado paralelo (uma verdadeira indústria) de vendas de bens desapropriados e precatórios com alto deságio, favorecendo aqueles que jogam contra o tempo (MORAES apud MAGALHĀES, 2019).

Portanto, no tocante às desapropriaçóes, mesmo que a indenização se faça de 
maneira prévia e justa, o efetivo recebimento, diante das diversas peculiaridades de modo cautelar que se encontram nesse procedimento de um processo lento e, também, por causa da morosidade do judiciário decorrente do grande volume de demandas, somente se concretizará após um grande decurso do tempo. Isso nos leva a crer que a adoçáo do regime de precatórios nessas demandas traria um prejuízo ainda maior ao particular quando de um prolongamento exacerbado, dada a realidade prática dos precatórios.

\subsection{Da repercussáo geral reconhecida no Recurso Extraordinário 922.144/MG}

Diante da incontroversa existente entre uma indenização prévia e a adoção do regime de precatórios para pagamento, o STF, em seu Recurso Extraordinário sob o número 922.144, ainda pendente de julgamento, reconheceu a repercussão geral da incontroversa, reconhecimento feito pelo ministro Luís Roberto Barroso. A processo originário de desapropriaçáo promovida pelo município de Juiz de Fora foi fixado pelo juízo de primeiro grau, o valor da indenização que seria efetuado, respeitando o regime de precatórios. Ambas as partes apelaram, mas o TJ/ MG manteve a sentença. As partes opuseram embargos de declaração, que foram rejeitados mantendo-se, portanto, a decisão e o entendimento da adoção do regime de precatórios nas açôes expropriatórias. O particular interpôs, então, recursos especial e extraordinário, e o município apenas recurso especial adesivo. No STJ, as pretensões recursais foram rejeitadas, ficando pendente, portanto, apenas o recurso extraordinário, reconhecida a repercussão geral, como podemos demonstrar:

DIREITO CONSTITUCIONAL E DIREITO ADMINISTRATIVO. DESAPROPRIAÇÃO. GARANTIA DE JUSTA E PRÉVIA INDENIZAÇÃO EM DINHEIRO. COMPATIBILIDADE COM O REGIME DE PRECATÓRIOS. PRESENÇA DE REPERCUSSÃO GERAL. 1. Constitui questão constitucional saber se e como a justa e prévia indenização em dinheiro assegurada pelo art. 5०, XXIV, da CRFB/1988 se compatibiliza com o regime de precatórios instituído no art. 100 da Carta. 2. Repercussão geral reconhecida.

REPERCUSSÃO GERAL NO RECURSO EXTRAORDINÁRIO 922.144 (MINAS GERAIS, 2015).

Para bem demonstrar a grande importância dada ao tempo, cabe ressaltar o fragmento do despacho que reconheceu a Repercussáo Geral no Recurso Extraordinário n. 922.144/MG: 
[...] Deixar de ser proprietário de um imóvel significa, muitas vezes, perder todo ou quase todo o patrimônio acumulado ao longo de uma vida, colocando em risco, muitas vezes, a própria subsistência do particular. Por outro lado, o regime de precatórios é essencial para a organização financeira do Estado. Exceçōes a ele devem ser vistas com bastante cautela, haja vista o potencial efeito desestabilizador das contas públicas (MINAS GERAIS, 2015).

O parágrafo supraexposto demonstra os dois interesses ressaltados por trás da indenização justa, prévia e em dinheiro para as desapropriações: a intervenção na propriedade em prol da sociedade, respeitando a dignidade garantida constitucionalmente do expropriado e a organização diante dos custos ao Erário.

Portanto, diante da controvérsia e a necessidade da uniformização do entendimento no que diz respeito à forma de pagamento das indenizaçóes nos casos concretos, espera-se que a jurisprudência da corte suprema, nesta nova oportunidade de análise do tema, realize o sopesamento das normas constitucionais em conflito e decida da maneira mais justa possível, buscando demonstrar qual regra prevalecerá ante as situaçóes enfrentadas, procedendo à uniformização do tema.

\section{Consideraçóes finais}

Conforme descrito no início deste trabalho, o direito de propriedade é garantido constitucionalmente, contudo o próprio texto estabelece que a propriedade deve atender a sua função social, uma vez que o Estado, para alcançar seus objetivos e assegurar a função social da propriedade, muitas das vezes, necessita intervir na propriedade privada.

Uma das modalidades de intervenção estatal é a desapropriação, que deve ter como base e fundamento a necessidade ou a utilidade pública ou o interesse social, como descrito constitucionalmente.

Após a efetiva desapropriação, haverá a transferência de um bem privado ou público (transferência aqui de um grau inferior ao superior) ao domínio estatal, mediante pagamento de indenização justa, prévia e, em regra, em dinheiro.

Posto isso, depois de demonstradas a utilidade e a necessidade pública ou de interesse social do poder público, este, por meio desse instituto, efetuará compulsoriamente a transferência da propriedade a seu patrimônio sempre observando o procedimento adequado previsto em nossa legislação, bem como realizará o efetivo pagamento de indenização como forma de equilíbrio entre o Estado e o particular, este último, que, diante da submissão ao interesse público, teve a perda de sua propriedade. 
Tal procedimento expropriatório e supressivo praticado em confronto com o direito de propriedade pode-se desencadear de um modo amigável por meio da esfera administrativa ou quando não houver acordo entre as partes. Pratica-se esse procedimento pela via judicial de modo a auferir o quantum indenizatório, ou seja, na esfera judicial. Quando esta for necessária, o magistrado além de observar os requisitos que compóem o procedimento, procederá à demanda apenas para determinar o valor da indenizaçâo a ser paga ao particular, já que diante da supremacia do interesse público sobre o privado, será realizada a desapropriação de maneira compulsória.

Depois de fixado o valor indenizatório a ser pago ao particular pela perda da propriedade, restam demonstrados a repartição doutrinária e os entendimentos superiores divergentes sobre como deverá ser realizado o pagamento da justa indenização.

Isso se dá porque a Constituiçấo Federal (BRASIL, 1988) descreve que os pagamentos devidos pelo poder público em virtude de sentença judiciária - que é o caso do valor fixado decorrente de desapropriação judicial -, deveráo obedecer a uma ordem cronológica de quitação, que constitui o regime de precatórios. Nesse regime, na prática, o que se percebe é que tal prazo não é observado, fazendo a demora incorrer em prejuízo ao particular diante da efetivação do ato supressivo do Estado.

Portanto, o que realmente justifica a divisão de entendimentos doutrinário e jurisprudencial, objeto principal deste artigo, reside no fato de que o pagamento da justa indenização decorrente da desapropriação judicial pela sistemática dos precatórios, seria incompatível com a norma constitucional de que, com respeito à indenização explicitamente prevista, deverá ser efetivada de maneira prévia, ou seja, antes da efetiva transferência da propriedade do bem ao poder público.

A legislação complementar em que se define o procedimento expropriatório também traz a possibilidade da imissáo provisória da posse do bem desapropriado no início do processo judicial. Desse modo, entende-se que essa possibilidade seria incompatível com o procedimento drástico demonstrado na desapropriação, em razão de estar previsto no texto constitucional a procedência do pagamento da indenização de maneira prévia. Ou seja, como o expropriado já foi desapropriado do bem pretendido, o pagamento da eventual diferença encontrada entre o valor depositado para fins de imissão provisória na posse e o montante fixado na sentença que declarou o valor da justa indenização não poderiam seguir o rito de precatórios previsto no art. 100 da Constituição Federal, em teoria, por não ser um regime que adota uma maneira prévia de ressarcimento e, na prática, por demonstrar atraso no procedimento. 
Há, portanto, uma nítida divergência judiciária na adoção da maneira como deverá ser realizada a indenização ao particular afetado pela intervenção Estatal na propriedade. No que diz respeito a essa divergência, o Egrégio Superior Tribunal Federal de relatoria do ministro Roberto Barroso, ainda pendente de análise pelo plenário, porém com repercussão geral reconhecida, nos termos do Recurso Extraordinário n. 922144/MG, reconheceu a grande importância do tema, sua relevância e sua repercussão geral constitucional suscitada (MINAS GERAIS, 2015).

É de suma importância demonstrar a introdução do direito de propriedade como status de direito fundamental, mas que, ao mesmo tempo e brilhantemente apresentado, diante de sua definição não tem uma condição absoluta, atrelada ao atendimento da função social e submetida ao interesse público quando devidamente demonstrada, ensejando, assim, o ato expropriatório.

Por fim, ao apresentar o instituto da desapropriação e a importância da indenização no procedimento, busca-se demonstrar os entendimentos jurisprudenciais e superiores sobre o tema, objeto deste trabalho, observando sua relevância que até mesmo teve sua repercussão geral reconhecida no Superior Tribunal Federal.

\section{Referências}

BRASIL. Presidência da República. Constituiçâo da República Federativa do Brasil de 1988. Brasília, DF: 1988. Disponível em: http://www.planalto.gov.br/ ccivil_03/constituicao/constituicaocompilado.htm. Acesso em: 8 jul. 2019.

BRASIL. Decreto-Lei n. 3.365, de 21 de junho de 1941. Dispóe sobre desapropriaçöes por utilidade pública. Brasília, DF: 1941. Disponível em: http://www.planalto.gov. br/ccivil_03/decreto-lei/del3365.htm. Acesso em: 10 out. 2019.

BRASIL. Lei n. 4.132, de 10 de setembro de 1962. Define os casos de desapropriação por interesse social e dispóe sobre sua aplicação. Brasília, DF: 1962. Disponível em: http://www.planalto.gov.br/ccivil_03/LEIS/L4132.htm. Acesso em: 10 out. 2019.

BRASIL. Lei n. 8.629, de 25 de fevereiro de 1993. Dispóe sobre a regulamentação dos dispositivos constitucionais relativos à reforma agrária, previstos no Capitulo III, Título VII, da Constituição Federal. Brasília, DF: 1993. Disponível em: http:// www.planalto.gov.br/ccivil_03/leis/L8629.htm. Acesso em: 10 out. 2019.

BRASIL. Lei n. 10.257, de 10 de julho de 2001. Regulamenta os arts. 182 e 183 da Constituição Federal, estabelece diretrizes gerais da política urbana e dá outras providências. Brasília, DF: 2001. Disponível em: http://www.planalto.gov.br/ ccivil_03/leis/leis_2001/110257.htm. Acesso em: 10 out. 2019. 
BRASIL. Supremo Tribunal Federal. Recurso Extraordinário n. 427.761/GO, Relator o Ministro Marco Aurélio, Primeira Turma, DJe: 30 maio 2008. Brasília, DF: 2008. Disponível em: http://redir.stf.jus.br/paginadorpub/paginador. jsp?docTP=TP\&docID=4887634. Acesso em: 13 nov. 2019.

BRASIL. Supremo Tribunal Federal. Recurso Extraordinário n. 739454/GO. AgR, Rel. Min. Cármen Lúcia, Segunda Turma, DJe 20 nov. 2013. Brasília, DF: 2013. Disponível em: https://stf.jusbrasil.com.br/jurisprudencia/24259951/ recurso-extraordinario-re-739454-go-stf. Acesso em: 13 nov. 2019.

CARVALHO FILHO, J. S. Manual de direito administrativo. 32. ed. rev. e atual. e ampl. São Paulo: Atlas, 2018.

CEARÁ. Tribunal de Justiça. Agravo de Instrumento: 06208428520158060000 CE 0620842-85.2015.8.06.0000. Relator Des. Washington Luís Bezerra de Araújo, 3a Câmara Direito Público. DEJ: 31 out. 2016. Disponível em: https:// tj-ce.jusbrasil.com.br/jurisprudencia/401083496/agravo-de-instrumentoai-6208428520158060000-ce-0620842-8520158060000/inteiro-teor401083511 ?ref=juris-tabs. Acesso em: 13 nov. 2019.

CRETELLA JR., J. Elementos de direito constitucional. 3. ed. São Paulo: Revista dos Tribunais, 2000.

DI PIETRO, M. S. Z. Curso de Direito Administrativo. 32. ed. Rio de Janeiro: Forense, 2019.

GOIÁS. Tribunal de Justiça/GO. Agravo de Instrumento n. 526688423.2017.8.09.0000, Rel. Des. Eudélcio Machado Fagundes, 3a Câmara Cível. Julgado em: 5 out. 2017. DJe: 5 out. 2017. Disponível em: https:// tj-go.jusbrasil.com.br/jurisprudencia/712285142/agravo-de-instrumento-cpcai-3076481720188090000/inteiro-teor-712285143. Acesso em: 13 nov. 2019.

GOMES, O. Direitos Reais. 20. ed. Rio de Janeiro: Forense.

LÔBO, P. Direito Civil: Direito das Coisas. 2. ed. São Paulo: Saraiva. 2016

MARINELA, F. Direito administrativo. 12. ed. São Paulo: Saraiva Educação, 2018. MAZZA, A. Manual de direito administrativo. 8. ed. São Paulo: Saraiva Educação, 2018.

MEDAUAR, O. Direito administrativo Moderno. 21. ed. Belo Horizonte: Fórum, 2018.

MINAS GERAIS. Supremos Tribunal Federal. Recurso Extraordinário n. 922144/ 
MG. Relator Min. Roberto Barroso. Data de Julgamento: 29 out. 2015. Data da Publicação: DJe 16 nov. 2015. Disponível em: http://portal.stf.jus.br/processos/ detalhe.asp?incidente $=4864567$. Acesso em: 13 nov. 2019 .

MINAS GERAIS. Supremo Tribunal Federal. Recurso Extraordinário n. 598678/ MG. AgR, Rel. Min. Eros Grau, Segunda Turma, DJe: 18 dez. 2009. Disponível em: https://stf.jusbrasil.com.br/jurisprudencia/5350052/recurso-extraordinariore-598678-mg-stf. Acesso em: 13 nov. 2019.

PARANÁ. Tribunal de Justiça/PR. AI: 13829559/PR. 1382955-9 (Acórdão). Relator Des. Carlos Mansur Arida. Data de Julgamento: 27 out. 2015, 5a Câmara Cível. DEJ: 17 nov. 2015. Disponível em: https://tj-pr.jusbrasil.com.br/ jurisprudencia/257226709/agravo-de-instrumento-ai-13829559-pr-1382955-9acordao. Acesso em: 13 nov. 2019.

PISCITELLI, T. Direito Financeiro Esquematizado. 2. ed. São Paulo: Gen. Método, 2012.

MAGALHÃES, M. T. R. Equilibrando tempo, usura e justa indenização na decisão da ADI 2.332. Portal CONJUR - Consultor Jurídico. 27 out. 2019. Disponível em: https://www.conjur.com.br/2019-out-27/observatorio-constitucional-equilibrando-tempo-usura-justa-indenizacao-adi-2332. Acesso em: 29 out. 2019.

TEPEDINO, G.; SCHREIBER, A. A garantia da propriedade no direito brasileiro. Revista da Faculdade de Direito de Campos, Campos dos Goytacazes, v. 6, n. 6, p. 101-119, jun. 2005. Disponível em: http://bdjur.stj.jus.br/dspace/ handle/2011/24705. Acesso em: 10 out. 2019. 